\title{
Nocardia inohanensis sp. nov., Nocardia yamanashiensis sp. nov. and Nocardia niigatensis sp. nov., isolated from clinical specimens
}

Correspondence
Yuzuru Mikami
mikami@myco.pf.chiba-u.ac.jp

\author{
Akiko Kageyama, Katsukiyo Yazawa, Kazuko Nishimura \\ and Yuzuru Mikami \\ Research Center for Pathogenic Fungi and Microbial Toxicoses, Chiba University, \\ 1-8-1 Inohana, Chuo-ku, Chiba 260-8673, Japan
}

\begin{abstract}
Comparative 16S rDNA studies on six strains of actinomycete isolated from clinical specimens revealed that they belong to the genus Nocardia and are closely related to Nocardia seriolae, Nocardia otitidiscaviarum, Nocardia uniformis, Nocardia pseudobrasiliensis and Nocardia crassostreae. However, the novel organisms consistently formed a clade distinct from that of the five latter species. Determination of DNA-DNA relatedness indicated that these strains could be classified under three novel species. Based on their phenotypic and phylogenetic characters, three novel species of the genus Nocardia are established: Nocardia inohanensis sp. nov. for IFM $0092^{\top}\left(=\right.$ NBRC $100128^{\top}=$ JCM $\left.11891^{\top}=\mathrm{DSM} 44667^{\top}\right)$, Nocardia yamanashiensis sp. nov. for IFM $0265^{\top}\left(=\right.$ NBRC $\left.100130^{\top}=\mathrm{JCM} 11893^{\top}=\mathrm{DSM} 44669^{\top}\right)$ and Nocardia niigatensis sp. nov. for IFM $0330^{\top}\left(=\right.$ NBRC $100131^{\top}=\mathrm{JCM} 11894^{\top}=\mathrm{DSM}$ $44670^{\top}$ ), IFM 0260, IFM 0636 and IFM 0833.
\end{abstract}

The genus Nocardia was proposed by Trevisan (1889) with the type species Nocardia asteroides. Many taxonomic studies (e.g. Schaal \& Reuterberg, 1978; Orchard \& Goodfellow, 1980) have reported that clinical isolates of $N$. asteroides are taxonomically heterogeneous. Clinical efforts to define specific subgroups of the species have been frustrated by the absence of readily available and reproducible testing methods (Wallace et al., 1995). Identification of subgroups of $N$. asteroides using phenotypic characters is largely unsuccessful when applied in the clinical laboratory. Many taxonomically ambiguous strains of Nocardia from clinical samples have been classified as $N$. asteroides. Recently, an identification method using drug susceptibility patterns was reported (Kiska et al., 2002; Roth et al., 2003). Identification with phylogenetic characters alone causes taxonomic confusion, but these simple methods are readily available.

Six strains from clinical specimens were initially identified as $N$. asteroides in our laboratory; however, the strains were found to have distinctive characters such as the ability to degrade hypoxanthine. Based on phylogenetic criteria, the

Published online ahead of print on 9 January 2004 as DOI 10.1099/ ijs.0.02794-0.

Abbreviation: MH, Mueller-Hinton II.

The DDBJ accession numbers for the 16S rDNA sequences of $N$. inohanensis IFM 0092 ${ }^{\top}, N$. yamanashiensis IFM 0265 ${ }^{\top}$ and $N$. niigatensis IFM 0260, $0330^{\top}, 0636$ and 0833 are respectively AB092560-AB092565. taxonomic position of these strains was determined and this revealed that these organisms consistently formed a distinct clade that was closely affiliated with Nocardia seriolae, Nocardia otitidiscaviarum, Nocardia uniformis, Nocardia pseudobrasiliensis and Nocardia crassostreae. From phenotypic and phylogenetic characters, coupled with data from genomic DNA-DNA relatedness levels, we propose the inclusion of these strains within the three novel species Nocardia inohanensis sp. nov., Nocardia yamanashiensis sp. nov. and Nocardia niigatensis sp. nov.

Strains IFM 0260, IFM $0265^{\mathrm{T}}$, IFM $330^{\mathrm{T}}$, IFM 0636 and IFM 0833 were isolated from skin abscesses from Japanese patients. Strain IFM 0260 was isolated in 1986 from a 63year-old male treated with corticosteroids, strain IFM $0265^{\mathrm{T}}$ was isolated in 1987 from a 30-year-old female patient, strain IFM $330^{\mathrm{T}}$ was isolated in 1990 from a 30-year-old male with systemic lupus erythematodes treated with corticosteroids, strain IFM 0636 was isolated in 1996 from a 53-year-old male with systemic lupus erythematodes treated with corticosteroids and strain IFM 0833 was isolated in 1998 from a 68-year-old male. Strain IFM $0092^{\mathrm{T}}$ was an isolate that has been kept in our laboratory since 1965 (originally isolated from a patient in Mexico by Ochoa Ochoa).

Strains IFM $0092^{\mathrm{T}}$, IFM 260, IFM $0265^{\mathrm{T}}$, IFM $330^{\mathrm{T}}$, IFM 0636 , IFM 0833, N. seriolae IFM $0286^{\mathrm{T}}, N$. uniformis IFM $0856^{\mathrm{T}}$ and $N$. otitidiscaviarum IFM $0239^{\mathrm{T}}$ were cultured on Muller-Hinton II (MH; Difco) slants with $1 \%$ glucose and 
$1 \%$ glycerol for 1 week at $30^{\circ} \mathrm{C}\left(25^{\circ} \mathrm{C}\right.$ for $N$. seriolae $)$. Strains IFM $0092^{\mathrm{T}}$, IFM 260, IFM $0265^{\mathrm{T}}$, IFM $330^{\mathrm{T}}$, IFM 0636 and IFM 0833 were cultured on MH plates with $1 \%$ glucose and $1 \%$ glycerol for 1 week at $30^{\circ} \mathrm{C}$ for colonization. The isolated strains were cultured on brain heart infusion (BHI; Difco) broth with $0 \cdot 1 \%$ glucose and $0 \cdot 1 \%$ glycerol for 5 days at $30^{\circ} \mathrm{C}$ for DNA sequencing and on BHI broth with $2 \%$ glucose and $2 \%$ glycine for 3 days at $30{ }^{\circ} \mathrm{C}\left(25^{\circ} \mathrm{C}\right.$ for $\mathrm{N}$. seriolae $)$ for DNA-DNA hybridization. Morphological observations under a scanning electron microscope (model S-5200; Hitachi) were made on cultures grown on $\mathrm{MH}$ agar with $0 \cdot 2 \%$ glucose or humic acid/ MOPS/gellan gum (HMG) medium (Suzuki et al., 2000) at $30{ }^{\circ} \mathrm{C}$ for $7-10$ days. For scanning electron microscopy, cultures were fixed in $2 \%$ osmium tetroxide vapour in situ at $25^{\circ} \mathrm{C}$ for $24 \mathrm{~h}$, dehydrated with ethanol and t-butanol and then freeze-dried. Each specimen was coated with osmium using an Osmium Plasma Coater OPC 80N (NLE Nippon Laser \& Electronics Lab).

Decomposition of adenine, casein, hypoxanthine, tyrosine, urea and xanthine and survival at $50{ }^{\circ} \mathrm{C}$ for $8 \mathrm{~h}$ were examined by using the methods of Gordon et al. (1974). Acid production from adonitol, arabinose, erythritol, galactose, glucose, inositol, maltose, mannose, rhamnose and sorbitol, utilization of citrate and gluconate and growth at 37 and $45^{\circ} \mathrm{C}$ were determined by the modified method of Poonwan et al. (1995). Isolated strains were tested for their ability to grow in $\mathrm{MH}$ agar with $0.2 \%$ glucose with each antibiotic TRIDISK (Eiken) at $32^{\circ} \mathrm{C}$ for 2 or 3 days (Mikami \& Yazawa, 1989).

Whole-cell hydrolysates were analysed for diaminopimelic acid (DAP) isomers using TLC (Staneck \& Roberts, 1974). Whole-cell sugars were prepared as reported elsewhere (Lechevalier \& Lechevalier, 1980) and analysed by TLC (Miyadoh, 2001). Mycolic acids were prepared as reported by Minnikin et al. (1980). Menaquinones were extracted from freeze-dried biomass $(500 \mathrm{mg})$ and analysed as described by Chun \& Goodfellow (1995).

A $1 \mathrm{ml}$ aliquot of Nocardia broth culture was centrifuged at 12000 r.p.m. for $10 \mathrm{~min}$. The pellet was resuspended in $200 \mu \mathrm{l}$ TE buffer, $250 \mu \mathrm{l}$ GPT reagent (6 M guanidine thiocyanate dissolved in $50 \mathrm{mM}$ Tris/ $\mathrm{HCl}, \mathrm{pH} \mathrm{8.3)}$ and $450 \mu \mathrm{l}$ Tris-buffered phenol $(\mathrm{pH} 8 \cdot 0)$. The tube was placed in a boiling water bath for $15 \mathrm{~min}$ and extracted with $250 \mu \mathrm{l}$ chloroform/isoamyl alcohol $(24: 1, \mathrm{v} / \mathrm{v})$. After $10 \mathrm{~min}$ centrifugation at 12000 r.p.m., the aqueous phase $(\sim 500 \mu \mathrm{l})$ was transferred to a fresh tube. The aqueous phase was mixed with $500 \mu \mathrm{l} 100 \%$ isopropanol and $50 \mu \mathrm{l} 3 \mathrm{M}$ sodium acetate and microcentrifuged at 12000 r.p.m. for $15 \mathrm{~min}$ at $4{ }^{\circ} \mathrm{C}$ before the supernatant was decanted. Traces of GPT reagent were removed by addition of $500 \mu$ ice-cold $70 \%$ ethanol to the nucleic acid pellet and samples were centrifuged at 12000 r.p.m. for $5 \mathrm{~min}$ at $4{ }^{\circ} \mathrm{C}$. The ethanol was then removed and the pellet dried under a vacuum for $20 \mathrm{~min}$. The pellet was finally resuspended in $50 \mu \mathrm{l}$ TE.
A nearly complete $16 \mathrm{~S}$ rRNA gene sequence was determined for each isolated strain. The $16 \mathrm{~S}$ rDNA was amplified by PCR and sequenced using the prokaryotic 16S rDNA universal primers $8 \mathrm{~F}$ ( $5^{\prime}$-AGAGTTTGATCCTGGCTCAG$\left.3^{\prime}\right)$ and 691R (5'-ACCGCTACACCAGGA- $\left.3^{\prime}\right)$, 520F $\left(5^{\prime}\right.$-CAGCAGCCGCGGTAATAC-3') and 1100R (5'-GGGTTGCGCTGTTG-3') and 926F (5'-AAACTCAAAGGAATTGACGG-3') and 1542R (5'-ACAAAGGAGGTGATC-3') in three separate reactions. PCR was performed with a DNA thermal cycler (TaKaRa) using 35 cycles of denaturation at $94{ }^{\circ} \mathrm{C}$ for $60 \mathrm{~s}$, primer annealing at $60^{\circ} \mathrm{C}$ for $60 \mathrm{~s}$ and primer extension at $72^{\circ} \mathrm{C}$ for $120 \mathrm{~s}$. PCR products were purified with Centri-Sep columns (Princeton Separations). DNA sequences were determined with an automatic sequence analyser (ABI PRISM 3100; PE Applied Biosystems) using a dye terminator cycle-sequencing kit (PE Applied Biosystems).

Species related to the novel isolates were identified by performing a sequence database search using BLAST. Sequence data for related species were retrieved from GenBank. Nucleotide substitution rates ( $K_{\text {nuc }}$ values) were calculated (Kimura \& Ohta, 1972) and phylogenetic trees were constructed by the neighbour-joining method (Saitou \& Nei, 1987). The statistical significance of the tree topology was evaluated by a bootstrap analysis of the sequence data with CLUSTAL W software (Thompson et al., 1994). The DNAML program in the PHYLIP package version 3.5c (Felsenstein, 1985) was used for maximum-likelihood analysis, with the default transition/transversion ratio of $2 \cdot 000000$. Sequence similarity values were determined by visual comparison and manual calculation.

For DNA base composition analysis and DNA-DNA hybridization, DNA was isolated as described by Saito \& Miura (1983) with modifications. DNA base compositions were estimated by HPLC (Tamaoka \& Komagata, 1984) and levels of DNA-DNA relatedness were determined by the method of Ezaki et al. (1989) using photobiotin and a microplate format.

The morphological and chemotaxonomic characters of the six novel isolates are consistent with their assignment to the genus Nocardia (Goodfellow, 1998; Goodfellow et al., 1999). All six isolates contained galactose and arabinose as characteristic whole-cell sugars in addition to meso-DAP as the predominant cell wall diamino acid. In addition, they all contained mycolic acids that co-migrated $\left(R_{\mathrm{f}}\right.$ value of about $0 \cdot 47)$ with those extracted from marker Nocardia strains. The major menaquinone of the six isolates was MK-8 $\left(\mathrm{H}_{4 \omega-\text {-cycl }}\right)$. 16S rDNA sequences were determined for all six strains, IFM $0092^{\mathrm{T}}$ (1442 bp), IFM 0260 (1499 bp), IFM $0265^{\mathrm{T}}(1414 \mathrm{bp})$, IFM $0330^{\mathrm{T}}(1405 \mathrm{bp})$, IFM 0636 (1493 bp), IFM 0833 (1492 bp), and a database search demonstrated that the strains belong to the suborder Corynebacterineae and the family Nocardiaceae (Stackebrandt et al., 1997).

The physiological properties of strains IFM $0092^{\mathrm{T}}$, IFM 
Table 1. Phenotypic properties that distinguish the novel strains from type strains of Nocardia species

Strains: $1, N$. inohanensis sp. nov. IFM $0092^{\mathrm{T}} ; 2$, N. yamanashiensis sp. nov. IFM $0265^{\mathrm{T}} ; 3$, N. niigatensis sp. nov. IFM 260, IFM $0330^{\mathrm{T}}$, IFM 0636 and IFM $0833 ; 4$, N. abscessus DSM $44432^{\mathrm{T}}$; 5, N. africana DSM 44491; 6, N. asteroides ATCC $19247^{\mathrm{T}} ; 7$, N. brasiliensis ATCC $19296^{\mathrm{T}}$; 8 , N. brevicatena DSM 43024 $;$; , N. beijingensis JCM $10666^{\mathrm{T}}$; 10 , N. carnea DSM $43397^{\mathrm{T}}$; 11, N. cerradoensis DSM 44546 $6^{\mathrm{T}}$; 12, N. crassostreae ATCC $70418^{\mathrm{T}}$; 13 , N. cummidelens DSM 44490; 14, N. cyriacigeorgica DSM 44484 $;$; 15 , N. farcinica ATCC $3318^{\mathrm{T}}$; 16 , N.

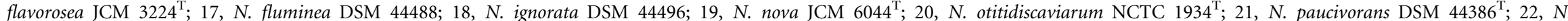

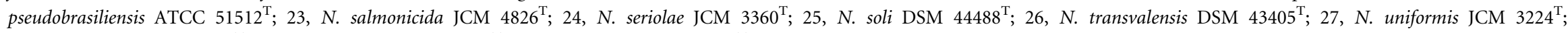
28, N. vaccinii DSM $43285^{\mathrm{T}} ; 29$, N. veterana DSM $44445^{\mathrm{T}}$; 30, N. vinacea JCM $10302^{\mathrm{T}}$. Data were taken from Albuquerque de Barros et al. (2003), Gürtler et al. (2001), Hamid et al. (2001), Kinoshita et al. (2001), Maldonado et al. (2000), Yassin et al. (2000, 2001a, b), Wang et al. (2001) and this study. Characters are scored as: +, positive; -, negative; w, weak; $(+)$, positive after 1 month; V, variable; ND, no data available.

\begin{tabular}{|c|c|c|c|c|c|c|c|c|c|c|c|c|c|c|c|c|c|c|c|c|c|c|c|c|c|c|c|c|c|c|}
\hline Character & 1 & 2 & 3 & 4 & 5 & 6 & 7 & 8 & 9 & 10 & 11 & 12 & 13 & 14 & 15 & 16 & 171 & 18 & 19 & 20 & 21 & 22 & 23 & 24 & 25 & 26 & 27 & 28 & 29 & 30 \\
\hline \multicolumn{31}{|l|}{ Decomposition of: } \\
\hline Adenine & - & - & - & - & - & - & - & - & - & - & -1 & ND & - & - & - & - & $-\mathrm{N}$ & ND & - & - & - & + & - & - & - & - & - & - & - & - \\
\hline Casein & - & - & - & - & + & - & + & - & - & - & - & - & - & - & - & - & -+ & + & - & - & - & + & - & - & - & - & - & - & - & - \\
\hline Hypoxanthine & + & + & w & - & - & - & + & - & - & - & - & - & - & - & - & - & - & - & - & + & - & + & - & - & - & + & + & - & - & + \\
\hline Tyrosine & - & - & - & - & - & - & + & - & - & - & - & - & - & - & - & - & +- & - & - & - & - & + & + & - & - & - & + & - & - & - \\
\hline Urea & + & + & $\mathrm{v}$ & $\mathrm{ND}$ & - & - & - & - & - & - & - & - & - & $\mathrm{ND}$ & - & + & $-\mathrm{N}$ & ND & - & + & $\mathrm{ND}$ & + & - & - & - & + & + & - & $\mathrm{ND}$ & + \\
\hline Xanthine & - & - & - & - & - & - & - & - & + & - & - & - & - & - & - & - & - & - & - & + & - & - & - & - & - & - & + & - & - & - \\
\hline \multicolumn{31}{|l|}{ Utilization of: } \\
\hline Adonitol & - & - & - & $\mathrm{ND}$ & $\mathrm{ND}$ & $\mathrm{ND}$ & $\mathrm{ND}$ & $\mathrm{ND}$ & $\mathrm{ND}$ & $\mathrm{ND}$ & ND & & $\mathrm{ND}$ & $\mathrm{ND}$ & $\mathrm{ND}$ & ND $\mathrm{r}$ & ND N & ND & ND & $\mathrm{ND}$ & ND & ND & ND & $\mathrm{ND}$ & ND & ND & & ND & $\mathrm{ND}$ & $\mathrm{ND}$ \\
\hline Arabinose & - & - & - & - & ND & - & - & ND & ND & ND & -1 & ND & ND & - & - & ND $\mathrm{r}$ & ND - & - & - & - & - & ND & - & ND & ND & - & ND & + & ND & ND \\
\hline Erythritol & - & - & - & - & ND & - & - & ND & ND & ND & -1 & ND & ND & - & - & ND $\mathrm{r}$ & ND - & - & - & - & - & ND & - & ND & ND & + & ND & - & ND & ND \\
\hline Galactose & - & - & - & - & ND & - & + & ND & ND & ND & -1 & ND & ND & - & - & ND $\mathrm{r}$ & ND - & - & + & - & - & ND & + & ND & ND & + & ND & + & ND & ND \\
\hline Glucose & + & + & + & + & $\mathrm{ND}$ & + & + & ND & ND & $\mathrm{ND}$ & +1 & $\mathrm{ND}$ & ND & - & + & ND $\mathrm{P}$ & $\mathrm{ND}+$ & + & + & + & - & $\mathrm{ND}$ & + & ND & $\mathrm{ND}$ & + & ND & + & $\mathrm{ND}$ & $\mathrm{ND}$ \\
\hline Inositol & + & + & $\mathrm{v}$ & - & $\mathrm{ND}$ & - & + & ND & ND & ND & -1 & $\mathrm{ND}$ & $\mathrm{ND}$ & - & - & ND $\mathrm{P}$ & ND - & - & - & + & - & $\mathrm{ND}$ & - & $\mathrm{ND}$ & $\mathrm{ND}$ & - & ND & - & ND & ND \\
\hline Maltose & - & - & $\mathrm{v}$ & + & $\mathrm{ND}$ & - & + & $\mathrm{ND}$ & ND & $\mathrm{ND}$ & ND : & $\mathrm{ND}$ & $\mathrm{ND}$ & - & + & ND $\mathrm{r}$ & $\mathrm{ND}+$ & + & - & - & - & $\mathrm{ND}$ & - & $\mathrm{ND}$ & $\mathrm{ND}$ & + & $\mathrm{ND}$ & - & $\mathrm{ND}$ & $\mathrm{ND}$ \\
\hline Mannose & $(+)$ & + & - & ND & $\mathrm{ND}$ & - & - & ND & ND & $\mathrm{ND}$ & +1 & $\mathrm{ND}$ & ND & $\mathrm{ND}$ & ND & ND $\mathrm{r}$ & ND N & ND & ND & $\mathrm{ND}$ & ND & ND & ND & $\mathrm{ND}$ & ND & ND & & $\mathrm{ND}$ & ND & ND \\
\hline Rhamnose & - & - & - & + & - & - & - & + & + & - & $+\mathrm{r}$ & $\mathrm{ND}$ & - & - & + & - & +- & - & - & - & - & - & - & - & + & + & - & + & + & - \\
\hline Sorbitol & - & - & - & - & - & - & - & - & + & + & +1 & $\mathrm{ND}$ & - & $\mathrm{ND}$ & - & - & $-\mathrm{N}$ & ND & + & - & - & + & + & - & - & + & - & - & ND & + \\
\hline Citrate & + & + & - & + & - & + & + & - & + & - & - & - & - & - & - & - & +- & - & - & - & - & + & + & + & - & - & - & - & - & ND \\
\hline Gluconate & - & + & - & $\mathrm{ND}$ & $\mathrm{ND}$ & $\mathrm{ND}$ & $\mathrm{ND}$ & $\mathrm{ND}$ & ND & $\mathrm{ND}$ & -1 & $\mathrm{ND}$ & ND & $\mathrm{ND}$ & ND & $\mathrm{ND} N$ & ND N & ND & $\mathrm{ND}$ & $\mathrm{ND}$ & ND & $\mathrm{ND}$ & $\mathrm{ND}$ & $\mathrm{ND}$ & ND & $\mathrm{ND}$ & & ND & ND & $\mathrm{ND}$ \\
\hline Growth at $37^{\circ} \mathrm{C}$ & + & + & + & ND & + & + & + & + & ND & + & $\mathrm{ND}$ & - & $\mathrm{ND}$ & $\mathrm{ND}$ & + & +1 & ND N & ND & + & + & ND & + & - & - & - & + & + & + & ND & + \\
\hline Growth at $45^{\circ} \mathrm{C}$ & - & - & - & - & + & - & + & - & - & - & - & - & - & $\mathrm{ND}$ & + & + & $-\mathrm{Nl}$ & & - & + & ND & - & - & - & - & - & - & - & + & - \\
\hline \multicolumn{31}{|l|}{ Susceptibility to:* } \\
\hline Imipenem $^{a}$ & +++ & +++ & - & + & +++ & +++ & - & ND & +++ & +++ & ND $\mathrm{P}$ & ND & +++ & +++ & +++ & ND $\mathrm{P}$ & ND N & $\mathrm{ND}+$ & +++ & - & +++ & +++ & +++ & $-\mathrm{ND}$ & +++ & +++ & ND & $\mathrm{ND}-$ & +++ & +++ \\
\hline Tobramycin $^{a}$ & +++ & + & +++ & +++ & + & +++ & +++ & $\mathrm{ND}$ & +++ & +++ & ND & $\mathrm{ND}$ & +++ & +++ & - & & ND N & & - & + & +++ & +++ & +++ & $-\mathrm{ND}$ & +++ & - & & $\mathrm{ND}$ & - & +++ \\
\hline Kanamycin $^{b}$ & +++ & +++ & +++ & ++ & +++ & + & - & $\mathrm{ND}$ & +++ & +++ & ND 1 & & - & - & - & ND 1 & ND N & & - & +++ & +++ & - & + & $\mathrm{ND}$ & - & - & & & ++ & - \\
\hline
\end{tabular}

*Scored as: $a$, growth at $10(+++), 5(++)$ or $2.5(+) \mathrm{mg}$ per disc or no growth with $2.5 \mathrm{mg}$ per disc $(-)$; $b$, growth at $30(+++), 10(++)$ or $5(+) \mathrm{mg}$ per disc or no growth with 5 mg per disc $(-)$. 

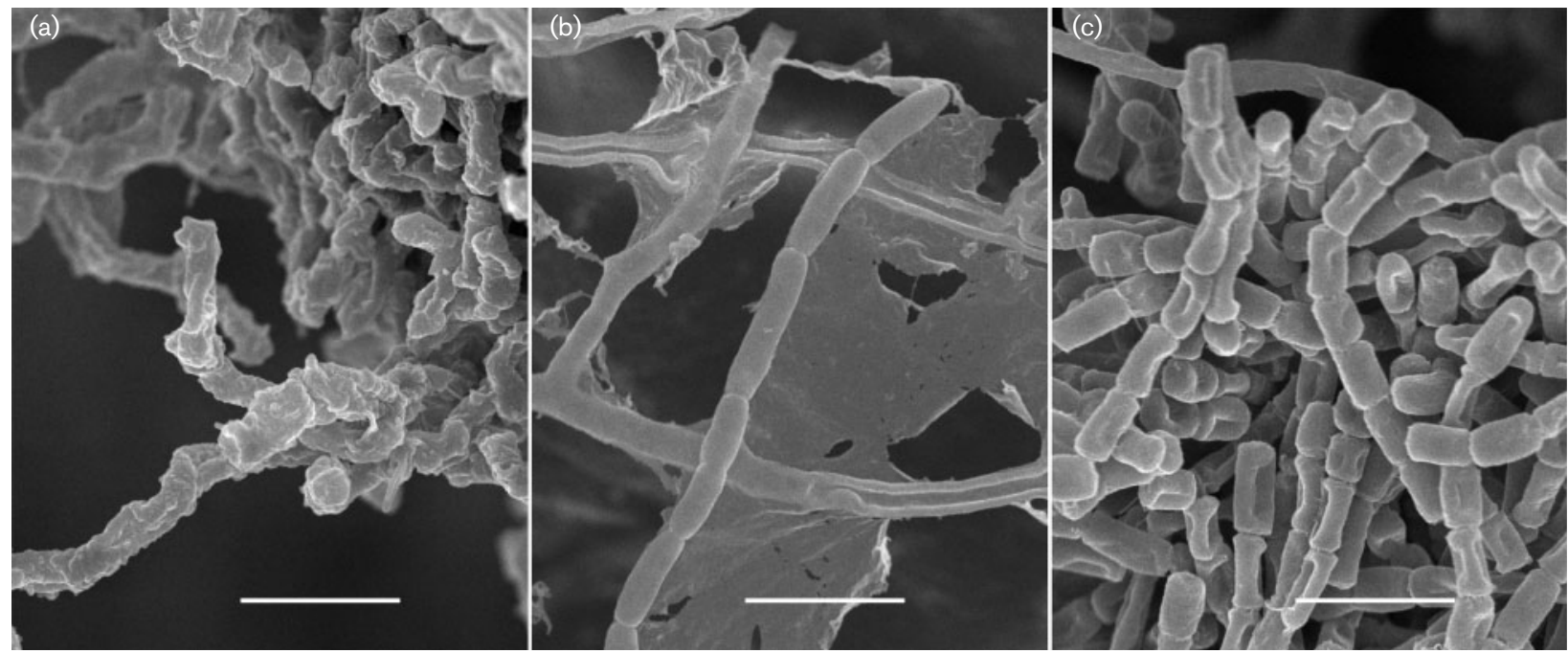

Fig. 1. Scanning electron micrographs of strain IFM $0092^{\top}$ (a) grown on HMG agar and strains IFM $0265^{\top}$ (b) and IFM $0330^{\top}$ (c) grown on $\mathrm{MH}$ agar with $0 \cdot 2 \%$ glucose at $30^{\circ} \mathrm{C}$ for 7 days. Bars, $2 \mu \mathrm{m}$.

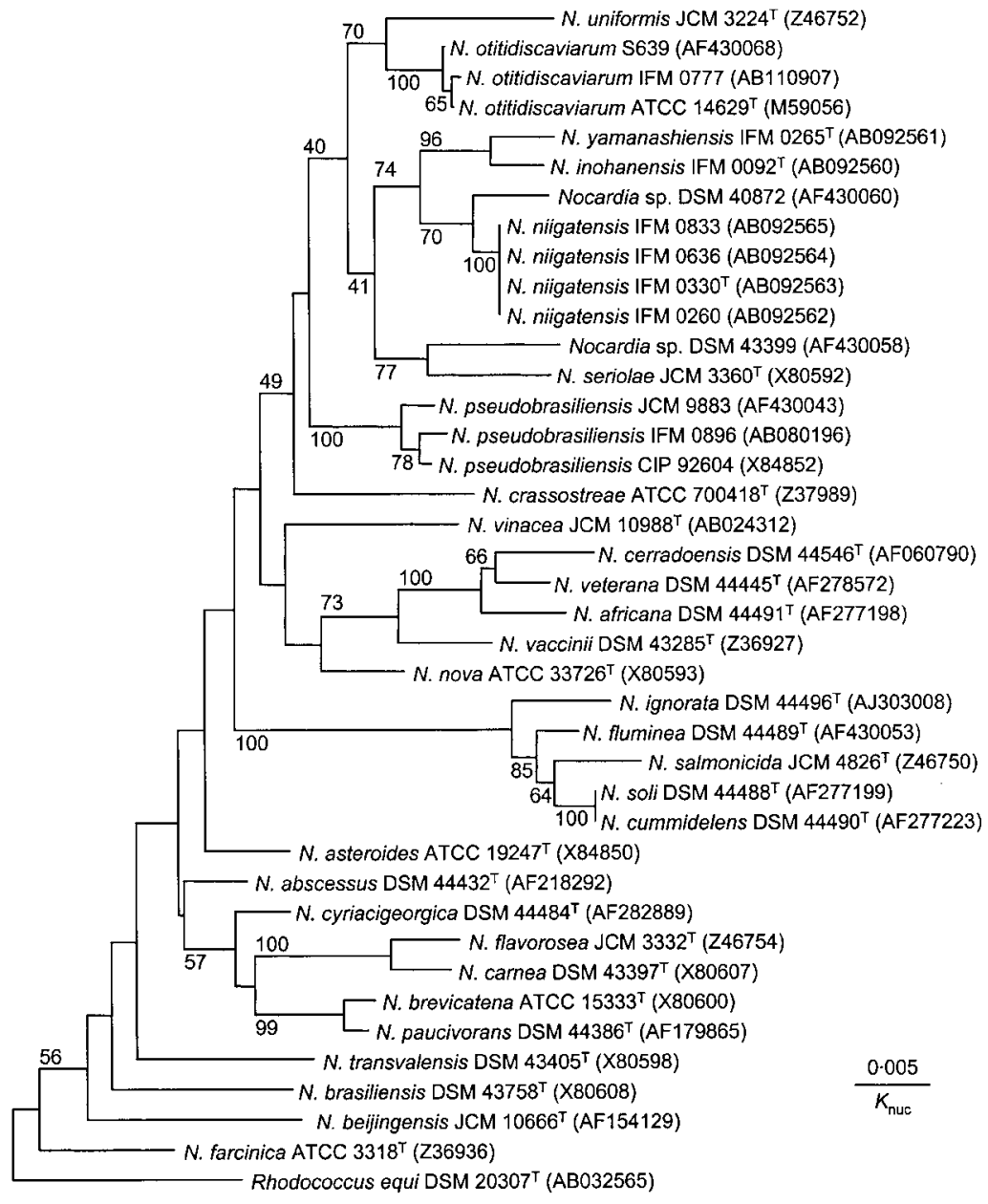

Fig. 2. Phylogenetic tree derived from $16 \mathrm{~S}$ rDNA sequences created using the neighbour-joining method and $K_{\text {nuc }}$ values. Numbers on the tree indicate bootstrap values for branch points; only values above $40 \%$ are indicated. The tree was unrooted and Rhodococcus equi was used as an outgroup. 
0260, IFM $0265^{\mathrm{T}}$, IFM $0330^{\mathrm{T}}$, IFM 0636 and IFM 0833 are shown in Table 1. Susceptibility testing of clinical isolates of Nocardia to antimicrobials is useful in grouping organisms. Strains IFM 0260, IFM $0330^{\mathrm{T}}$, IFM 0636 and IFM 0833 were negative for imipenem, which is very characteristic. The six strains were found to have the ability to decompose hypoxanthine, which is also characteristic. Fig. 1 shows cells of strains IFM $0092^{\mathrm{T}}$, IFM $0265^{\mathrm{T}}$ and IFM $0330^{\mathrm{T}}$ under a scanning electron microscope.

It was clear from phylogenetic trees (Figs 2 and 3) that the six strains could be divided into two clusters. Strains IFM $0092^{\mathrm{T}}$ and IFM $0265^{\mathrm{T}}$ comprised one cluster and the remaining strains, IFM 0260, IFM $0330^{\mathrm{T}}$, IFM 0636 and IFM 0833, made another cluster. Nocardia sp. DSM 40872 and Nocardia sp. DSM 43399 are novel, unnamed strains of the genus Nocardia (Roth et al., 2003). From a BLAST search, these novel strains were closely related to the six isolated strains. Sequence similarity among IFM 0260, IFM $0330^{\mathrm{T}}$, IFM 0636 and IFM 0833 was $99 \cdot 6-99 \cdot 9 \%$. This is very high, and is sufficient to indicate that these four strains belong to the same species. The sequence similarity between IFM $0092^{\mathrm{T}}$ and IFM $0265^{\mathrm{T}}$ was $99.0 \%$ (14 base differences). The closest neighbour of IFM $0092^{\mathrm{T}}$ amongst species with validly published names was $N$. uniformis, with $97 \cdot 5 \%$ sequence similarity (34 differences). The closest neighbours of IFM $0265^{\mathrm{T}}$ and IFM $0330^{\mathrm{T}}$ were respectively $N$. otitidiscaviarum (97.7\% similarity; 35 differences) and N. seriolae $(97 \cdot 8 \%$ similarity; 31 differences). We therefore checked the similarity of these strains based on DNA-DNA hybridization with $N$. seriolae IFM $0286^{\mathrm{T}}$, N. otitidiscaviarum IFM $0239^{\mathrm{T}}$ and $N$. uniformis IFM $0856^{\mathrm{T}}$ (Table 2). DNA-DNA relatedness among the four isolates IFM 0260, IFM $0330^{\mathrm{T}}$, IFM 0636 and IFM 0833 was $>80 \%$ and relatedness to other species with validly published names was $<41 \%$, showing that these strains represent a single novel species. Strains IFM $0092^{\mathrm{T}}$ and IFM $0265^{\mathrm{T}}$ formed a cluster and the sequence similarity between the two strains was $99.0 \%$; however, DNA-DNA hybridization values (40-44\%) showed that strains IFM $0092^{\mathrm{T}}$ and IFM $0265^{\mathrm{T}}$ could each represent a novel species (Table 2 ).

In conclusion, the six isolated strains can be divided into three novel species of Nocardia. These three novel species and other Nocardia species were differentiated by biochemical phenotypes. From these studies on phenotypic characters and also the phylogenetic analysis, the names Nocardia inohanensis sp. nov., Nocardia yamanashiensis sp. nov. and Nocardia niigatensis sp. nov. are proposed.

\section{Description of Nocardia inohanensis sp. nov.}

Nocardia inohanensis (in.o.han.en'sis. N.L. fem. adj. inohanensis pertaining to Inohana, Chiba, Japan, where the type strain was identified).

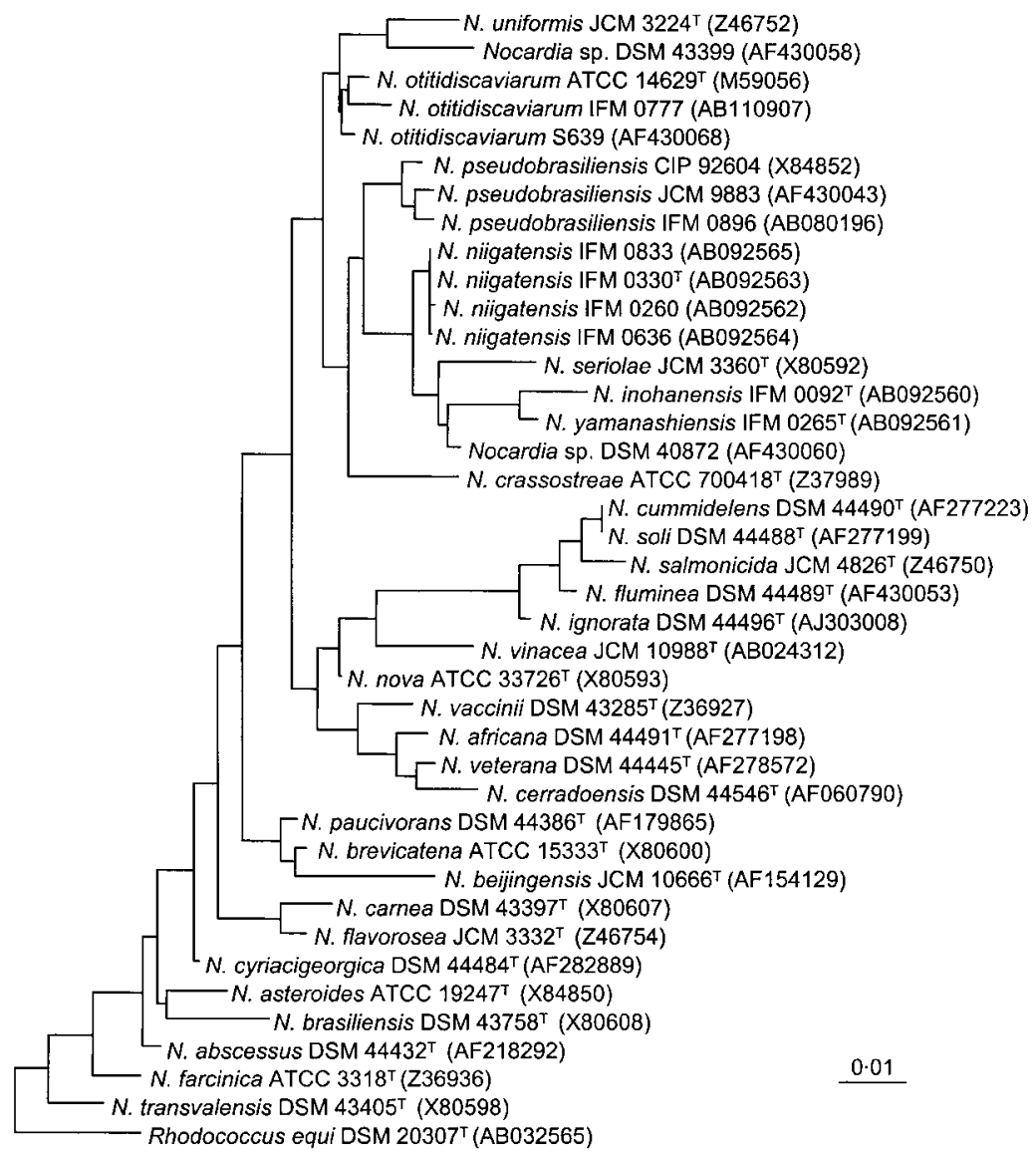

Fig. 3. Phylogenetic tree derived from $16 S$ rDNA sequences using maximum-likelihood analysis. The tree was unrooted and Rhodococcus equi was used as an outgroup. 
Table 2. Levels of DNA-DNA relatedness among the six novel Nocardia strains and related type strains

\begin{tabular}{|c|c|c|c|c|c|c|c|c|c|}
\hline Strain & 1 & 2 & 3 & 4 & 5 & 6 & 7 & 8 & 9 \\
\hline 1. IFM $0092^{\mathrm{T}}$ & 100 & 40 & 20 & 21 & 32 & 28 & 33 & 23 & 22 \\
\hline 2. IFM $0265^{\mathrm{T}}$ & 44 & 100 & 24 & 29 & 19 & 22 & 29 & 25 & 27 \\
\hline 3. IFM 0260 & 14 & 22 & 100 & 98 & 95 & 97 & 44 & 17 & 24 \\
\hline 4. IFM $0330^{\mathrm{T}}$ & 10 & 21 & 99 & 100 & 92 & 95 & 42 & 20 & 25 \\
\hline 5. IFM 0636 & 11 & 18 & 93 & 93 & 100 & 92 & 37 & 18 & 24 \\
\hline 6. IFM 0833 & 23 & 18 & 94 & 88 & 90 & 100 & 36 & 18 & 23 \\
\hline 7. N. seriolae IFM $0286^{\mathrm{T}}$ & 13 & 20 & 38 & 41 & 29 & 31 & 100 & 18 & 33 \\
\hline 8. N. otitidiscaviarum IFM $0239^{\mathrm{T}}$ & $7 \cdot 7$ & 13 & 16 & 20 & 14 & 14 & 14 & 100 & 33 \\
\hline 9. N. uniformis IFM $0856^{\mathrm{T}}$ & 17 & $8 \cdot 2$ & 15 & 22 & 18 & 16 & 16 & 19 & 100 \\
\hline
\end{tabular}

Colonies are greyish-tan to tan. Cells show typical Nocardia micromorphology: branched vegetative mycelium that fragments into bacteroid, rod-shaped, non-motile elements. Aerial mycelium is only visible microscopically. No soluble pigment produced. Short chains of conidia can be seen on the tips of aerial mycelium. Gram-positive and partially acid-fast, as determined by the modified Kinyoun method ( $1 \%$ sulfuric acid decolorization). Colonies are $0 \cdot 6-1 \cdot 3 \mathrm{~mm}$ in diameter after 7 days at $30^{\circ} \mathrm{C}$ on $\mathrm{MH}$ medium with $0 \cdot 2 \%$ glucose. Glucose, inositol and citrate are utilized, but not adonitol, arabinose, erythritol, galactose, maltose, mannose, rhamnose, sorbitol or gluconate. Hypoxanthine and urea are decomposed, but not adenine, casein, tyrosine or xanthine. Grows at $37^{\circ} \mathrm{C}$ but not at $45^{\circ} \mathrm{C}$. The $\mathrm{G}+\mathrm{C}$ content of DNA is $69 \cdot 3 \mathrm{~mol} \%$.

The type strain, strain IFM $0092^{\mathrm{T}}\left(=\mathrm{NBRC} 100128^{\mathrm{T}}=\mathrm{JCM}\right.$ $11891^{\mathrm{T}}=$ DSM $\left.44667^{\mathrm{T}}\right)$, was isolated from clinical material.

\section{Description of Nocardia yamanashiensis sp. nov.}

Nocardia yamanashiensis (ya.ma.na.shi.en'sis. N.L. fem. adj. yamanashiensis pertaining to Yamanashi prefecture of Japan, the source of the type strain).

Colonies are greyish-tan to tan. Cells have typical Nocardia micromorphology: branched vegetative hyphae that fragment into bacteroid, rod-shaped to coccoid elements. Aerial hyphae are sparse on most media used and are visible microscopically. Gram-positive and partially acid-fast, as determined by the modified Kinyoun method ( $1 \%$ sulfuric acid decolorization). Colonies are $1 \cdot 0-1 \cdot 9 \mathrm{~mm}$ in diameter after 7 days at $30{ }^{\circ} \mathrm{C}$ on $\mathrm{MH}$ medium with $0 \cdot 2 \%$ glucose. Glucose, inositol, citrate and gluconate are utilized, but not adonitol, arabinose, erythritol, galactose, maltose, mannose, rhamnose or sorbitol. Hypoxanthine and urea are decomposed, but not adenine, casein, tyrosine or xanthine. Grows at $37^{\circ} \mathrm{C}$ but not at $45^{\circ} \mathrm{C}$. The $\mathrm{G}+\mathrm{C}$ content of DNA is $69 \cdot 2 \mathrm{~mol} \%$.

The type strain, strain IFM $0265^{\mathrm{T}}\left(=\mathrm{NBRC} 100130^{\mathrm{T}}=\mathrm{JCM}\right.$ $\left.11893^{\mathrm{T}}=\mathrm{DSM} 44669^{\mathrm{T}}\right)$, was isolated from clinical material.

\section{Description of Nocardia niigatensis sp. nov.}

Nocardia niigatensis (ni.i.gat.en'sis. N.L. fem. adj. niigatensis pertaining to Niigata, Japan, the source of the isolate).

Colonies are orange-tan to greyish-tan. Cells have typical Nocardia micromorphology: branched vegetative hyphae that fragment into oval to rod-shaped elements. Aerial mycelium is sparse and white and has a patchy distribution. Short chains of conidia may be found on the aerial mycelium. Faint brown soluble pigment produced. Gram-positive and partially acid-fast, as determined by the modified Kinyoun method ( $1 \%$ sulfuric acid decolorization). Colonies are $1 \cdot 5-3 \cdot 2 \mathrm{~mm}$ in diameter after 7 days at $30^{\circ} \mathrm{C}$ on $\mathrm{MH}$ medium with $0 \cdot 2 \%$ glucose. Glucose is utilized, but not adonitol, arabinose, erythritol, galactose, maltose, mannose, rhamnose, sorbitol or citrate. Hypoxanthine is weakly decomposed, but not adenine, casein, tyrosine or xanthine. Grows at $37^{\circ} \mathrm{C}$ but not at $45^{\circ} \mathrm{C}$. The $\mathrm{G}+\mathrm{C}$ content of DNA is $68 \cdot 8-69 \cdot 5 \mathrm{~mol} \%$.

The type strain is strain IFM $0330^{\mathrm{T}} \quad(=\mathrm{NBRC}$ $\left.100131^{\mathrm{T}}=\mathrm{JCM} 11894^{\mathrm{T}}=\mathrm{DSM} 44670^{\mathrm{T}}\right)$. Strains have been isolated from clinical material.

\section{Acknowledgements}

We thank Dr T. Tamura and Dr K. Suzuki (National Institute of Technology and Evaluation) for advice on scanning electron microscopic observation.

\section{References}

Albuquerque de Barros, E. V. S., Manfio, G. P., Ribeiro Maitan, V., Mendes Bataus, L. A., Kim, S. B., Maldonado, L. A. \& Goodfellow, M. (2003). Nocardia cerradoensis sp. nov., a novel isolate from Cerrado soil in Brazil. Int J Syst Evol Microbiol 53, 29-33.

Chun, J. \& Goodfellow, M. (1995). A phylogenetic analysis of the genus Nocardia with $16 \mathrm{~S}$ rRNA gene sequences. Int J Syst Bacteriol 45, 240-245.

Ezaki, T., Hashimoto, Y. \& Yabuuchi, E. (1989). Fluorometric deoxyribonucleic acid-deoxyribonucleic acid hybridization in microdilution wells as an alternative to membrane filter hybridization in which radioisotopes are used to determine genetic relatedness among bacterial strains. Int J Syst Bacteriol 39, 224-229. 
Felsenstein, J. (1985). Confidence limits on phylogenies: an approach using the bootstrap. Evolution 39, 783-791.

Goodfellow, M. (1998). Nocardia and related genera. In Topley and Wilson's Microbiology and Microbial Infections, 9th edn, vol. 2, Systematic Bacteriology, pp. 463-489. Edited by A. Balows \& B. I. Duerden. London: Arnold.

Goodfellow, M., Isik, K. \& Yates, E. (1999). Actinomycete systematics: an unfinished synthesis. Nova Acta Leopold 80 (312), 47-82.

Gordon, R. E., Barnett, D. A., Handerhan, J. E. \& Pang, C. H.-N (1974). Nocardia coeliaca, Nocardia autotrophica, and the nocardin strain. Int J Syst Bacteriol 24, 54-63.

Gürtler, V., Smith, R., Mayall, B. C., Pötter-Reinemann, G., Stackebrandt, E. \& Kroppenstedt, R. M. (2001). Nocardia veterana sp. nov., isolated from human bronchial lavage. Int J Syst Evol Microbiol 51, 933-936.

Hamid, M. E., Maldonado, L., Sharaf Eldin, G. S., Mohamed, M. F., Saeed, N. S. \& Goodfellow, M. (2001). Nocardia africana sp. nov., a new pathogen isolated from patients with pulmonary infections. $J$ Clin Microbiol 39, 625-630.

Kimura, M. \& Ohta, T. (1972). On the stochastic model for estimation of mutational distance between homologous proteins. J Mol Evol 2, 87-90.

Kinoshita, N., Homma, Y., Igarashi, M., Ikeno, S., Hori, M. \& Hamada, M. (2001). Nocardia vinacea sp. nov. Actinomycetologica 15, $1-5$.

Kiska, D. L., Hicks, K. \& Pettit, D. J. (2002). Identification of medically relevant Nocardia species with an abbreviated battery of tests. J Clin Microbiol 40, 1346-1351.

Lechevalier, M. P. \& Lechevalier, H. (1970). Chemical composition as a criterion in the classification of aerobic actinomycetes. Int J Syst Bacteriol 20, 435-443.

Lechevalier, M. P. \& Lechevalier, H. A. (1980). The chemotaxonomy of actinomycetes. In Actinomycete Taxonomy, pp. 227-291. Edited by A. Dietz \& D. W. Thayer. Arlington, VA: Society for Industrial Microbiology.

Lechevalier, M. P., De Bièvre, C. \& Lechevalier, H. A. (1977). Chemotaxonomy of aerobic actinomycetes: phospholipid composition. Biochem Syst Ecol 5, 249-260.

Maldonado, L., Hookey, J. V., Ward, A. C. \& Goodfellow, M. (2000). The Nocardia salmonicida clade, including descriptions of Nocardia cummidelens sp. nov., Nocardia fluminea sp. nov. and Nocardia soli sp. nov. Antonie van Leeuwenhoek 78, 367-377.

Mikami, Y. \& Yazawa, K. (1989). Susceptibility patterns of pathogenic Nocardia to some selected antimicrobial agents and their usefulness in the identification work in a clinical laboratory. Bull JFCC 5, 89-95.

Minnikin, D. E., Hutchinson, I. G., Caldicott, A. B. \& Goodfellow, M. (1980). Thin-layer chromatography of methanolysates of mycolic acid-containing bacteria. J Chromatogr 188, 221-233.

Miyadoh, M. (2001). Identification procedure at the genus level. In Identification Manual of Actinomycetes, pp. 9-19. Edited by S. Miyadoh, M. Hamada, K. Hotta, T. Kudo, A. Seino, K. Suzuki \& A. Yokota. Tokyo: Business Center for Academic Societies.
Orchard, V. A. \& Goodfellow, M. (1980). Numerical classification of some named strains of Nocardia asteroides and related isolates from soil. J Gen Microbiol 118, 295-312.

Poonwan, N., Kusum, M., Mikami, Y., Yazawa, K., Tanaka, Y., Gonoi, T., Hasegawa, S. \& Konyama, K. (1995). Pathogenic Nocardia isolated from clinical specimens including those of AIDS patients in Thailand. Eur J Epidemiol 11, 507-512.

Roth, A., Andrees, S., Kroppenstedt, R. M., Harmsen, D. \& Mauch, H. (2003). Phylogeny of the genus Nocardia based on reassessed 16S rRNA gene sequences reveals underspeciation and division of strains classified as Nocardia asteroides into three established species and two unnamed taxons. J Clin Microbiol 41, 851-856.

Saito, H. \& Miura, K. (1983). Preparation of transforming deoxyribonucleic acid by phenol treatment. Biochim Biophys Acta 72, 619-629.

Saitou, N. \& Nei, M. (1987). The neighbor-joining method: a new method for reconstructing phylogenetic trees. Mol Biol Evol 4, 406-425.

Schaal, K. P. \& Reuterberg, H. (1978). Numerical taxonomy of Nocardia asteroides. Zentbl Bakteriol Parasitol Infekt Hyg I Abt Suppl 6, 53-62.

Stackebrandt, E., Rainey, F. A. \& Ward-Rainey, N. L. (1997). Proposal for a new hierarchic classification system, Actinobacteria classis nov. Int J Syst Bacteriol 47, 479-491.

Staneck, J. L. \& Roberts, G. D. (1974). Simplified approach to identification of aerobic actinomycetes by thin-layer chromatography. Appl Microbiol 28, 226-231.

Suzuki, S., Yamamoto, K., Okuda, T., Nishino, M., Nakanishi, N. \& Komatsubara, S. (2000). Selective isolation and distribution of Actinomadura rugatobispora strains in soil. Actinomycetologica 14, 27-33.

Tamaoka, J. \& Komagata, K. (1984). Determination of DNA base composition by reversed-phase high-performance liquid chromatography. FEMS Microbiol Lett 25, 125-128.

Thompson, J. D., Higgins, D. G. \& Gibson T. J. (1994). CLUSTAL W: improving the sensitivity of progressive multiple sequence alignment through sequence weighting, position-specific gap penalties and weight matrix choice. Nucleic Acids Res 22, 4673-4680.

Wallace, R. J., Jr, Brown, B. A., Blacklock, Z. \& 7 other authors (1995). New Nocardia taxon among isolates of Nocardia brasiliensis associated with invasive disease. J Clin Microbiol 33, 1528-1533.

Wang, L., Zhang, Y., Lu, Z., Shi, Y., Liu, Z., Maldonado, L. \& Goodfellow, M. (2001). Nocardia beijingensis sp. nov., a novel isolate from soil. Int J Syst Evol Microbiol 51, 1783-1788.

Yassin, A. F., Rainey, F. A., Mendrock, U., Brzezinka, H. \& Schaal, K. P. (2000). Nocardia abscessus sp. nov. Int J Syst Evol Microbiol 50, 1487-1493.

Yassin, A. F., Rainey, F. A. \& Steiner, U. (2001a). Nocardia cyriacigeorgici sp. nov. Int J Syst Evol Microbiol 51, 1419-1423.

Yassin, A. F., Rainey, F. A. \& Steiner, U. (2001b). Nocardia ignorata sp. nov. Int J Syst Evol Microbiol 51, 2127-2131. 